\title{
Non-traditional stable isotope signatures in geological matrices as a tool for interpreting environmental changes - a review
}

\author{
Željka Fiket*, Martina Furdek Turk, Maja Ivanić and Goran Kniewald
}

Ruđer Bošković Institute, Division for Marine and Environmental Research, Bijenička cesta 54, 10000 Zagreb, Croatia; ( ${ }^{*}$ correspondence: zeljka.fiket@irb.hr)

doi: $10.4154 / g c .2021 .12$

Article history:

Manuscript received November 11, 2020

Revised manuscript accepted March 29, 2021

Available online June 30, 2021

\begin{abstract}
The development of new analytical techniques enabled the precise determination of the expanded set of stable isotopes and provided new insight into existing geological issues. This review outlines recent studies of non-traditional isotope signatures in geological matrices, summarizing in one place, new data for the stable isotopes of $\mathrm{Ca}, \mathrm{Mg}, \mathrm{Sr}, \mathrm{Li}, \mathrm{Ni}, \mathrm{Cr}$, and $\mathrm{Cu}$ and their application in the interpretation of environmental processes. Although some, such as $\delta^{44} \mathrm{Ca}$ and $\delta^{26} \mathrm{Mg}$, have previously been used to track changes in seawater chemistry throughout geological history, recent studies report their application as geochemical proxies of post-depositional processes. Similarly, isotopic signatures of strontium, previously used in radioactive isotope chronology, and $\delta^{7} \mathrm{Li}$, used in tracing plate subduction and crust/mantle material cycling, found a new application in studies of weathering patterns. The use of $\delta^{53} \mathrm{Cr}$ and $\delta^{65} \mathrm{Cu}$ isotope signatures, on the other hand, reflects their fractionation under different redox conditions, whereas $\delta^{60} \mathrm{Ni}$, due to its adsorption and co-precipitation with sulfide species and Fe-Mn phases, is used in interpreting the contributions of different material sources. And while the isotopic signatures of all these elements indicate certain environmental conditions and processes (e.g. post-depositional processes, redox conditions, organic matter input, the contribution of sources, etc.), by combining them a more comprehensive insight into the investigated environment can be achieved.
\end{abstract}

Keywords: non-traditional isotopes; $\mathrm{Ca}$ and $\mathrm{Mg}$ $\mathrm{Sr}$ and Li; transition metals; geological matrices biological activity), as well as in deciphering the contributions of different sources. While the isotopic signatures of $\mathrm{Li}, \mathrm{Sr}, \mathrm{Ca}$, and $\mathrm{Mg}$ in sediments as indicators of subduction and continental crust formation or as age and temperature palaeo-proxies have been widely discussed in the literature (NÄGLER et al., 2000; BÖHM et al., 2006; CHAN et al., 2006; HIPPLER et al., 2006; FANTLE \& TIPPER, 2014; SAENGER \& WANG, 2014; TENG, 2017; GUO et al., 2019), their use in the interpretation of postdepositional processes has only recently been more extensively investigated (FANTLE \& HIGGINS, 2014; CHANDA \& FANTLE, 2017; TENG et al., 2017; BRADBURY \& TURCHYN, 2018; HU et al., 2019; LI et al., 2019). The same applies to the application of isotopic variability of the transition metals as a tool for solving specific problems in palaeo- and recent environmental settings (GUEGUEN et al., 2016; BACONNAIS et al., 2018; LITTLE et al., 2018; BRUGGMANN et al., 2019). To date, research on the latter is extremely scarce and additional efforts need to be made to produce a more comprehensive database on the isotope variability of these elements in different matrices.

Although the existing literature provides a valuable overview of the current knowledge on non-traditional isotopes, it most often relates to only one, rarely several, isotopes together (CHAN et al., 2006; FANTLE \& HIGGINS, 2014; LITTLE et al., 2014; BLÄTTLER et al., 2015; CHANDA \& FANTLE, 2017; LITTLE et al., 2017; BACONNAIS et al., 2018; BRADBURY \& TURCHYN, 2018; CISCATO et al., 2018; BRUGGMANN et al., 2019; HU et el., 2019; LI et al., 2019). However, the intertwining of different processes occurring simultaneously in an environment necessitates the use of larger data sets that include more stable isotopes as well as their total element concentrations. The review presented here thus provides an overview of the latest research on the subject, summarizing in one place new data on non-
$\mathrm{Cu}$ ) group in the interpretation of post-depositiona cesses and environmental conditions (i.e. redox conditions and 
traditional isotopes $(\mathrm{Ca}, \mathrm{Mg}, \mathrm{Sr}, \mathrm{Li}, \mathrm{Ni}, \mathrm{Cr}$, and $\mathrm{Cu})$ in different geological environments and highlighting the need for a comprehensive database that would allow us to properly argue their use in interpreting environmental changes through Earth's history. The listed elements were selected as those that have found new applications with the development of spectrometry techniques or as representatives of a group of transition metals the isotopic composition of which is nowadays used in the interpretation of numerous processes in palaeo- and recent environments.

\section{STABLE ISOTOPES AND NOTATION}

Nowadays, stable isotope determinations are generally performed on multi-collector inductively coupled plasma mass spectrometry instruments (MC-ICP-MS; e.g. Nu instruments, UK or Neptune, Thermo-Fisher, Bremen, Germany) (e.g. BLÄTTLER et al., 2015; LITTLE et al., 2014; LITTLE et al., 2017; CISCATO et al., 2018; HU et al., 2019; etc.). Detailed guidelines and recommended terms for expressing stable isotope ratios, as well as a description of the assessment of international reference materials for isotope-ratio analysis, can be found elsewhere (COPLEN, 2011; BRAND et al., 2014). The following are the elements described in this review paper, their isotopes, and an explanation of associate isotope composition records.

Magnesium has three stable isotopes, ${ }^{24} \mathrm{Mg},{ }^{25} \mathrm{Mg}$ and ${ }^{26} \mathrm{Mg}$, with the relative abundances of $78.99 \%, 10.00 \%$ and $11.01 \%$, respectively, whereas there are six naturally occurring calcium isotopes: ${ }^{40} \mathrm{Ca},{ }^{42} \mathrm{Ca},{ }^{43} \mathrm{Ca},{ }^{44} \mathrm{Ca},{ }^{46} \mathrm{Ca}$ and ${ }^{48} \mathrm{Ca}$, with abundances of $96.941 \%, 0.647 \%, 0.135 \%, 2.086 \%, 0.004 \%$ and $0.187 \%$, respectively.

Magnesium stable isotope data are reported using the standard per mil (\%) notation of $\delta^{26} \mathrm{Mg}$, i.e., the per mil deviation of the measured ${ }^{26} \mathrm{Mg} /{ }^{24} \mathrm{Mg}$ ratios of the unknowns relative to those of the international $\delta$-zero reference material DSM3. Although the DSM3 reference material is no longer available and has now been replaced by the ERM-AE143, calibrated to the DSM3, results are still reported vs. DSM3:

$\delta^{26} \mathrm{Mg}=$

$\left[\left({ }^{26} \mathrm{Mg} /{ }^{24} \mathrm{Mg}\right)_{\text {sample }} /\left({ }^{26} \mathrm{Mg} /{ }^{24} \mathrm{Mg}\right)_{\mathrm{DSM} 3}-1\right] \times 1000$

For $\mathrm{Ca}$, the isotopic composition is expressed in \%o relative to the international standard reference material NIST SRM 915a or $\mathrm{b}$, as $\delta^{44 / 40} \mathrm{Ca}$ or $\delta^{44} \mathrm{Ca}$.

$\delta^{44} \mathrm{Ca}=$

$\left[\left({ }^{44} \mathrm{Ca} /{ }^{40} \mathrm{Ca}\right)_{\text {sample }} /\left({ }^{44} \mathrm{Ca} /{ }^{40} \mathrm{Ca}\right)_{\text {NIST SRM } 915 \mathrm{a} / \mathrm{b}}-1\right] \times 1000$

Strontium is an alkali-earth metal with four stable naturally occurring isotopes; ${ }^{84} \mathrm{Sr},{ }^{86} \mathrm{Sr},{ }^{87} \mathrm{Sr}$, and ${ }^{88} \mathrm{Sr}$, whereby ${ }^{87} \mathrm{Sr}$ is also partly radiogenic, being produced by beta-decay of the radionuclide ${ }^{87} \mathrm{Rb}$ with a half-life of $48.8 \times 10^{9}$ years (SEMENISHCHEV et al., 2020). Contrary to the ${ }^{87} \mathrm{Sr} /{ }^{86} \mathrm{Sr}$ ratio that gradually increases over time, the proportion between ${ }^{84} \mathrm{Sr},{ }^{86} \mathrm{Sr}$, and ${ }^{88} \mathrm{Sr}$ is constant in nature, but can change in processes where natural fractionation of isotopes occurs (SEMENISHCHEV et al., 2020).

For $\mathrm{Sr}$, the stable isotopic composition is expressed in \%o relative to the international standard reference material SRM987 (NIST):

$\delta^{88} \mathrm{Sr}=\left[\left({ }^{88} \mathrm{Sr} /{ }^{86} \mathrm{Sr}_{\text {sample }}\right) /\left({ }^{88} \mathrm{Sr} /{ }^{86} \mathrm{Sr}_{\mathrm{SRM}} 987\right)-1\right] \times 1000$
Unlike the $\delta^{88} \mathrm{Sr}$ ratio, expressed in per mil, the relative proportion of radiogenic to stable $\mathrm{Sr}$ isotopes, i.e. ${ }^{87} \mathrm{Sr} /{ }^{86} \mathrm{Sr}$ isotopic ratio, has commonly been reported in terms of a four- to six-place decimal notation instead of $\delta$-notation.

Lithium was one of the few elements produced during the Big Bang nucleosynthesis. It is composed of two stable isotopes ${ }^{6} \mathrm{Li}$ and ${ }^{7} \mathrm{Li}$, with the heavier one being far more abundant $(92.41 \%)$. Its isotopic composition is expressed in \% relative to the international standard reference material NIST L-SVEC or IRMM-016 (LI et al., 2010) as $\delta^{7} \mathrm{Li}$ values:

$\delta^{7} \mathrm{Li}=\left[\left({ }^{7} \mathrm{Li} /{ }^{6} \mathrm{Li}\right)_{\text {sample }} /\left({ }^{7} \mathrm{Li} /{ }^{6} \mathrm{Li}\right)_{\text {standard }}-1\right] \times 1000$

Naturally occurring nickel is composed of five stable isotopes: ${ }^{58} \mathrm{Ni},{ }^{60} \mathrm{Ni},{ }^{61} \mathrm{Ni},{ }^{62} \mathrm{Ni}$, and ${ }^{64} \mathrm{Ni}$, with ${ }^{58} \mathrm{Ni}$ being the most abundant (68.077\% natural abundance), and 26 radioisotopes. Its isotopic composition is expressed in \% relative to the international standard reference material NIST SRM 986 as $\delta^{60} \mathrm{Ni}$ values:

$\delta^{60} \mathrm{Ni}=\left[\left({ }^{60} \mathrm{Ni} /{ }^{58} \mathrm{Ni}\right)_{\text {sample }} /\left({ }^{60} \mathrm{Ni} /{ }^{58} \mathrm{Ni}\right)_{\mathrm{SRM}} 986-1\right] \times 1000$

Naturally occurring chromium is composed of four stable isotopes: ${ }^{50} \mathrm{Cr},{ }^{52} \mathrm{Cr},{ }^{53} \mathrm{Cr}$, and ${ }^{54} \mathrm{Cr}$, with ${ }^{52} \mathrm{Cr}$ being the most abundant $(83.789 \%$ natural abundance). Its isotopic composition is expressed in \%o relative to the international standard reference material NIST SRM 979 as $\delta^{53} \mathrm{Cr}$ values:

$\delta^{53} \mathrm{Cr}=\left[\left({ }^{53} \mathrm{Cr} /{ }^{52} \mathrm{Cr}\right)_{\text {sample }} /\left({ }^{53} \mathrm{Cr} /{ }^{52} \mathrm{Cr}\right)\right.$ SRM $\left.979-1\right] \times 1000$

Copper has two stable isotopes, ${ }^{63} \mathrm{Cu}(69.17 \%)$ and ${ }^{65} \mathrm{Cu}$ (30.83\%), along with 27 radioisotopes. Natural mass-dependent variations in ${ }^{65} \mathrm{Cu} /{ }^{63} \mathrm{Cu}$ span $15 \%$, and are expressed relative to the NIST SRM 976 standard as $\delta^{65} \mathrm{Cu}$ values:

$\delta^{65} \mathrm{Cu}=\left[\left({ }^{65} \mathrm{Cu} /{ }^{63} \mathrm{Cu}\right)_{\text {sample }} /\left({ }^{65} \mathrm{Cu} /{ }^{63} \mathrm{Cu}\right)_{\text {SRM } 976}-1\right] \times 1000$

\section{NON-TRADITIONAL ISOTOPES AS GEOCHEMICAL PROXIES OF POST-DEPOSITIONAL PROCESSES}

\subsection{Weathering}

The radiogenic Sr isotope ratio $\left({ }^{87} \mathrm{Sr} r{ }^{86} \mathrm{Sr}\right)$ has long been known as a reliable tool in geochronological studies as well as in provenance investigation. Namely, the radiogenic ${ }^{87} \mathrm{Sr} /{ }^{86} \mathrm{Sr}$ ratio generally varies with age and $\mathrm{Rb} / \mathrm{Sr}$ ratios result in the ${ }^{87} \mathrm{Sr} /{ }^{86} \mathrm{Sr}$ ratio being an excellent tracer for the source(s) of $\mathrm{Sr}$ (ANDREWS et al., 2016; SEMENISHCHEV et al., 2020) (Table 1). However, with recent advances in mass-spectrometry, small variations in stable Sr isotope abundances (reported as $\delta^{88} \mathrm{Sr}$ ) can be accurately quantified (FIETZKE \& EISENHAUER, 2006; OHNO \& HIRATA, 2007) and are increasingly used to gain further insight into the $\mathrm{Sr}$ cycle and its primary controls (ANDREWS et al., 2016). So far, the fractionation of the stable isotopes of $\mathrm{Sr}$ has been documented in terrestrial, marine, and biological processes; wherein the lighter $\delta^{86} \mathrm{Sr}$ isotopes are preferentially incorporated into biogenic carbonates $(+0.14 \%$ to $+0.27 \%$, KRABBENHÖF et al., 2010), while inorganic Ca-carbonates and seawater are enriched in the heavy $\mathrm{Sr}$ isotope and therefore display more positive $\delta^{88} \mathrm{Sr}$ values $(+0.25 \%$ to $+0.37 \%$ in carbonates (HALICZ et al., 2008); $0.310(8) \%$ as an average value for seawater (KRABBENHÖF et al., 2010); $0.407 \pm 0.012 \%$ in seawater from the Pacific and Atlantic oceans (WAKAKI et al., 2017); or $0.35 \pm 0.06 \%$ for 
Table 1. Strontium and lithium isotope composition in different types of samples.

\begin{tabular}{|c|c|c|c|}
\hline Isotope & $\delta$ & Sample type & Reference \\
\hline \multirow{21}{*}{$\delta^{88} \mathrm{Sr}$} & $+0.310(8) \% 0$ & seawater, average & KRABBENHÖF et al., 2010 \\
\hline & $+0.407 \% \circ \pm 0.012 \%$ & Pacific and Atlantic seawater & WAKAKI et al., 2017 \\
\hline & $+0.39 \%$ $\pm 0.02 \%$ & deep Pacific seawater & SCHER et al., 2013 \\
\hline & $+0.14 \%$ o to $+0.27 \%$ o & marine biogenic carbonates & KRABBENHÖF et al., 2010 \\
\hline & $+0.27 \%$ o to $+0.37 \%$ o & marine inorganic carbonates & HALICZ et al., 2008 \\
\hline & $+0.35 \%$ $\pm 0.06 \%$ & Mediterranean Sea & HALICZ et al., 2008 \\
\hline & $-0.17 \% \circ \pm 0.06 \%$ & terra rossa soil and speleothem calcite & HALICZ et al., 2008 \\
\hline & $+0.26 \% 0 \pm 0.1 \%$ & aragonite & HALICZ et al., 2008 \\
\hline & $+0.22 \% \circ \pm 0.07 \%$ & corals & HALICZ et al., 2008 \\
\hline & $+0.35 \%$ $\pm 0.06 \%$ & seawater & HALICZ et al., 2008 \\
\hline & $-0.14 \%$ o to $-0.20 \%$ o & terrestrial carbonates & HALICZ et al., 2008 \\
\hline & $+0.253 \%$ o to $0.361 \%$ o & hydrothermal fluids & KRABBENHÖF et al., 2010 \\
\hline & $+0.28 \% 0 \pm 0.09 \%$ & gneiss & DE SOUZA et al., 2010 \\
\hline & $+0.15 \%$ o to $+0.31 \%$ o & granite & DE SOUZA et al., 2010 \\
\hline & $+0.29 \%$ o to $+0.31 \%$ o & soil & DE SOUZA et al., 2010 \\
\hline & $+0.24 \%$ o to $+0.42 \%$ o & rivers & KRABBENHÖF et al., 2010 \\
\hline & $+0.27 \%$ o to $+0.33 \%$ o & river sediments & ANDREWS et al., 2016 \\
\hline & $\sim 0.267 \%$ & carbonate fraction of soils and sediments & ANDREWS et al., 2016 \\
\hline & $\sim 0.263 \%$ & silicate fraction of soils and sediments & ANDREWS et al., 2016 \\
\hline & $+0.223 \%$ o to $+0.369 \%$ o & soil exchangeable fraction & ANDREWS et al., 2016 \\
\hline & $-0.11 \%$ o to $+0.42 \%$ o & plants & OESER \& BLANCKENBURG, 2020 \\
\hline \multirow{33}{*}{$\delta^{7} \mathbf{L i}$} & $+31 \%$ & ocean seawater & PENNISTON-DORLAND et al., 2017 \\
\hline & $+1 \%$ o to $+44 \%$ o & river water & PENNISTON-DORLAND et al., 2017 \\
\hline & $+17 \%$ o to $+35 \%$ o & lake water & PENNISTON-DORLAND et al., 2017 \\
\hline & $+6 \%$ o to $+29 \%$ o & groundwater & PENNISTON-DORLAND et al., 2017 \\
\hline & $+5 \%$ o to $+11 \%$ o & hydrothermal fluids & PENNISTON-DORLAND et al., 2017 \\
\hline & $-3 \%$ to $+26 \%$ & geothermal waters & PENNISTON-DORLAND et al., 2017 \\
\hline & $31 \%$ & seawater & CHAN et al., 2006 \\
\hline & $-2 \%$ o to $5 \%$ & clays & CHAN et al., 2006 \\
\hline & $-4.3 \%$ o to $+14.5 \%$ o & marine sediments & CHAN et al., 2006 \\
\hline & $-1.5 \%$ o to $+5 \%$ & clay rich detrital sediments & CHAN et al., 2006 \\
\hline & $+0.5 \%$ o to $+3.6 \%$ & Laki basalts (Hawaii) & PISTINER \& HENDERSON, 2003 \\
\hline & $+2.2 \%$ to $+4.7 \%$ o & Hawaii soil & PISTINER \& HENDERSON, 2003 \\
\hline & $+9.8 \%$ & rainwater (unfiltered) & PISTINER \& HENDERSON, 2003 \\
\hline & $+18.1 \%$ & rainwater (filtered) & PISTINER \& HENDERSON, 2003 \\
\hline & $+2.4 \%$ o to $+4.6 \%$ & basalt & PISTINER \& HENDERSON, 2003 \\
\hline & $+8.8 \%$ o to $+9.1 \%$ o & granite & PISTINER \& HENDERSON, 2003 \\
\hline & $+3.1 \%$ o to $+12.0 \%$ o & Sao Miguel rivers bedload & POGGE VON STRANDMANN et al., 2010 \\
\hline & $+3.5 \%$ to $+9.5 \%$ & Sao Miguel rivers suspended load & POGGE VON STRANDMANN et al., 2010 \\
\hline & $+18.2 \%$ o to $+36.2 \%$ o & Sao Miguel rivers dissolved load & POGGE VON STRANDMANN et al., 2010 \\
\hline & $+5.9 \%$ o to $+9.8 \%$ o & $\begin{array}{l}\text { Sao Miguel rivers dissolved load in rivers influenced by } \\
\text { hydrothermal input }\end{array}$ & POGGE VON STRANDMANN et al., 2010 \\
\hline & $+6.9 \%$ & Sao Miguel hot spring & POGGE VON STRANDMANN et al., 2010 \\
\hline & $+32.8 \%$ & Sao Miguel rivers rainwater & POGGE VON STRANDMANN et al., 2010 \\
\hline & $+2.8 \%$ o to $+8.9 \%$ & Iceland rivers bedload & POGGE VON STRANDMANN et al., 2006 \\
\hline & $-1.3 \%$ o to $7.5 \%$ o & Iceland rivers suspended load & POGGE VON STRANDMANN et al., 2006 \\
\hline & $+17.0 \%$ o to $+43.7 \%$ o & Iceland rivers dissolved load & POGGE VON STRANDMANN et al., 2006 \\
\hline & $+10.9 \%$ & Iceland hot spring & POGGE VON STRANDMANN et al., 2006 \\
\hline & $+22.8 \% 0$ & Hraunfossar, Iceland groundwater & POGGE VON STRANDMANN et al., 2006 \\
\hline & $+33.3 \%$ & Ice (Iceland) & POGGE VON STRANDMANN et al., 2006 \\
\hline & $+0.6 \% 0 \pm 0.6 \%$ & continental crust & SAUZÉAT et al., 2015 \\
\hline & $0 \% \circ \pm 2 \%$ & continental crust & TENG et al., 2004 \\
\hline & $+6 \%$ to $+32 \%$ & carbonates & POGGE VON STRANDMANN et al., 2019 \\
\hline & $6.1 \% 0 \pm 1.3 \% 0$ & seawater calcite & POGGE VON STRANDMANN et al., 2019 \\
\hline & $9.6 \% 0 \pm 0.6 \%$ & seawater aragonite & POGGE VON STRANDMANN et al., 2019 \\
\hline
\end{tabular}

the Mediterranean Sea (HALICZ et al., 2008; Table 1), analogous to Ca isotopes. Still, the Sr isotopic fractionation in terrestrial and marine systems is relatively small, with $\delta^{88} \mathrm{Sr}$ values varying by $2.5 \%$ (FIETZKE \& EISENHAUER, 2006; OHNO \& HIRATA, 2007; KRABBENHÖF et al., 2010; ANDREWS et al., 2016; WAKAKI et al., 2017; SEMENISHCHEV et al., 2020).
Compared to other elements and isotopes, Sr is unique in that its isotopic records contain information on both the source of $\mathrm{Sr}$ $\left({ }^{87} \mathrm{Sr} r{ }^{86} \mathrm{Sr}\right)$ and the mass-fractionating processes that it has witnessed $\left(\delta^{88} \mathrm{Sr}\right)$. The combined application of these data can thus lead to a more comprehensive understanding of the weathering cycle of Sr. The latter was also suggested by MÍKOVÁ (2012) in 
her review on tracing weathering processes and flow pathways in surface and ground waters in Antarctica and terrains with a retreating glacier using strontium isotopic composition. A similar approach was also adopted by ANDREWS et al. (2016) using radiogenic $\mathrm{Sr}$ isotope ratios $\left({ }^{87} \mathrm{Sr} /{ }^{86} \mathrm{Sr}\right)$, stable $\mathrm{Sr}$ isotope ratios $\left({ }^{88} \mathrm{Sr}\right)$, and major ion data to identify river cation sources and their biogeochemical cycling within the Cleddau and Hollyford River catchments in the Milford Sound region of Fiordland, New Zealand. Their results suggested that the soil water $\delta^{88} \mathrm{Sr}$ values are $\sim 0.30 \%$ higher than the bedrock $\delta^{88} \mathrm{Sr}$ values, while mixing calculations showed that the plant-fractionated soil water pool contributes $\sim 27 \%$ of the riverine Sr. Also, by combining the $\delta^{88} \mathrm{Sr}$ values and $\mathrm{Ca} / \mathrm{Sr}$ and ${ }^{87} \mathrm{Sr} /{ }^{86} \mathrm{Sr}$ ratios, three major contributions to the $\mathrm{Sr}$ riverine budget in the Milford Sound region were identified; i) silicate (with $\delta^{88} \mathrm{Sr}$ amounting to $\sim 0.263 \%$ ); ii) carbonate weathering (with $\delta^{88} \mathrm{Sr}$ amounting to $\sim 0.264 \%$ ); iii) soil water input (with $\delta^{88} \mathrm{Sr}$ between $0.223 \%$ and $0.369 \%$ ). Similarly, continental waters were found to be enriched with ${ }^{88} \mathrm{Sr}$ compared to the rocks in their drainage basins (e.g. KRABBENHÖF et al., 2010; MOYNIER et al., 2010). To explain this phenomenon, SHALEV et al. (2017) suggested that during precipitation of continental carbonates (i.e. carbonates precipitated from the surface, pedogenic, or groundwater) a fractionation of strontium isotopes occurs that contributes to the enrichment of ${ }^{88} \mathrm{Sr}$ in rivers. However, this would also require that a surprisingly large proportion ( $40 \%)$ of the originally weathered $\mathrm{Sr}$ to co-precipitate with continental carbonates, suggesting that some other mechanisms, such as Sr uptake in plants and/or incongruent weathering of silicates, play a significant role in the Sr cycle (SHALEV et al., 2017). OESER \& BLACKENBURG (2020) concluded that the release of Sr during weathering is isotopically congruent and that, despite a strong biological fractionation $(-0.40 \%$ to $+0.34 \% 0)$, the plant production - degradation cycle is isotopically neutral. The potential fractionation in the bioavailable Sr pool was explained by the loss of $\mathrm{Sr}$ from the system by organic solids enriched in the light ${ }^{86} \mathrm{Sr}$ isotope.

The understanding of stable $\mathrm{Sr}$ isotope fractionation during weathering is however, still very limited (HALICZ et al., 2008;
DE SOUZA et al., 2010; SHALEV ET AL., 2017) (Table 1), and necessitates further investigation.

In addition to $\mathrm{Sr}, \mathrm{Li}$ isotopes have also been reported as contributing to a better understanding of weathering processes (Fig. 1). Namely, the significant fractionation of Li isotopes occurs during silicate weathering, from over $26 \%$ and up to $35 \%$ in river and surface environments (PISTINER \& HENDERSON, 2003), with the preferential incorporation of ${ }^{6} \mathrm{Li}$ in neo-formed clay minerals (e.g. PISTINER \& HENDERSON, 2003; POGGE VON STRANDMANN et al., 2010; SAUZÉAT et al., 2015), and the mobilization of heavier ${ }^{7} \mathrm{Li}$ into solution. On continents, the $\delta^{7} \mathrm{Li}$ value is thus controlled by the leaching rates of silicate source rocks and the amounts of neo-formed clays. Consequently, areas with weathering-limited regimes (e.g. mountainous or glaciated regions), as well as those with transport-limited regimes (e.g. areas with thick soil sequences), are usually characterized by high $\delta^{7} \mathrm{Li}$ signatures, except when underlain by shales. In rivers, the $\delta^{7} \mathrm{Li}$ isotopic signature is driven by the lithology of the drainage area, where the primary lithology determines the secondary mineralogy (e.g. POGGE VON STRANDMANN et al., 2006; 2010; SAUZÉAT et al., 2015), the corresponding weathering intensity, the concentration of river suspended load (POGGE VON STRANDMANN et al., 2006;), as well as the subsurface residence time of infiltrating meteoric waters (PISTINER \& HENDERSON, 2003; SAUZÉAT et al., 2015) (Table 1). All the latter conditions show significantly greater variability of $\delta^{7} \mathrm{Li}$ in rivers. For example, in river waters the $\delta^{7} \mathrm{Li}$ is $+1 \%$ to $+44 \%$ (PENNISTON-DORLAND et al., 2017), $-1.3 \%$ to $+9.5 \%$ in the suspended load (POGGE VON STRANDMANN et al., 2006; 2010), and $17.0 \%$ to $43.7 \%$ in the dissolved load (POGGE VON STRANDMANN et al., 2006; 2010), while in silicate rocks the values are $\sim 0 \%$ in the continental crust (TENG et al., 2004; SAUZÉAT et al., 2015) and $\sim 3-5 \%$ in basalts (PISTINER \& HENDERSON, 2003; SAUZÉAT et al., 2015). Marine sediments are, on the other hand, enriched in heavier ${ }^{7} \mathrm{Li}$, with $\delta^{7} \mathrm{Li}$ values ranging from $4.3 \%$ to $+14.5 \%$ (CHAN et al., 2006), while carbonates display an even broader range and generally correspond to $\delta^{7} \mathrm{Li}$ values between $+6 \%$ and $+32 \%$ (POGGE VON STRANDMANN et

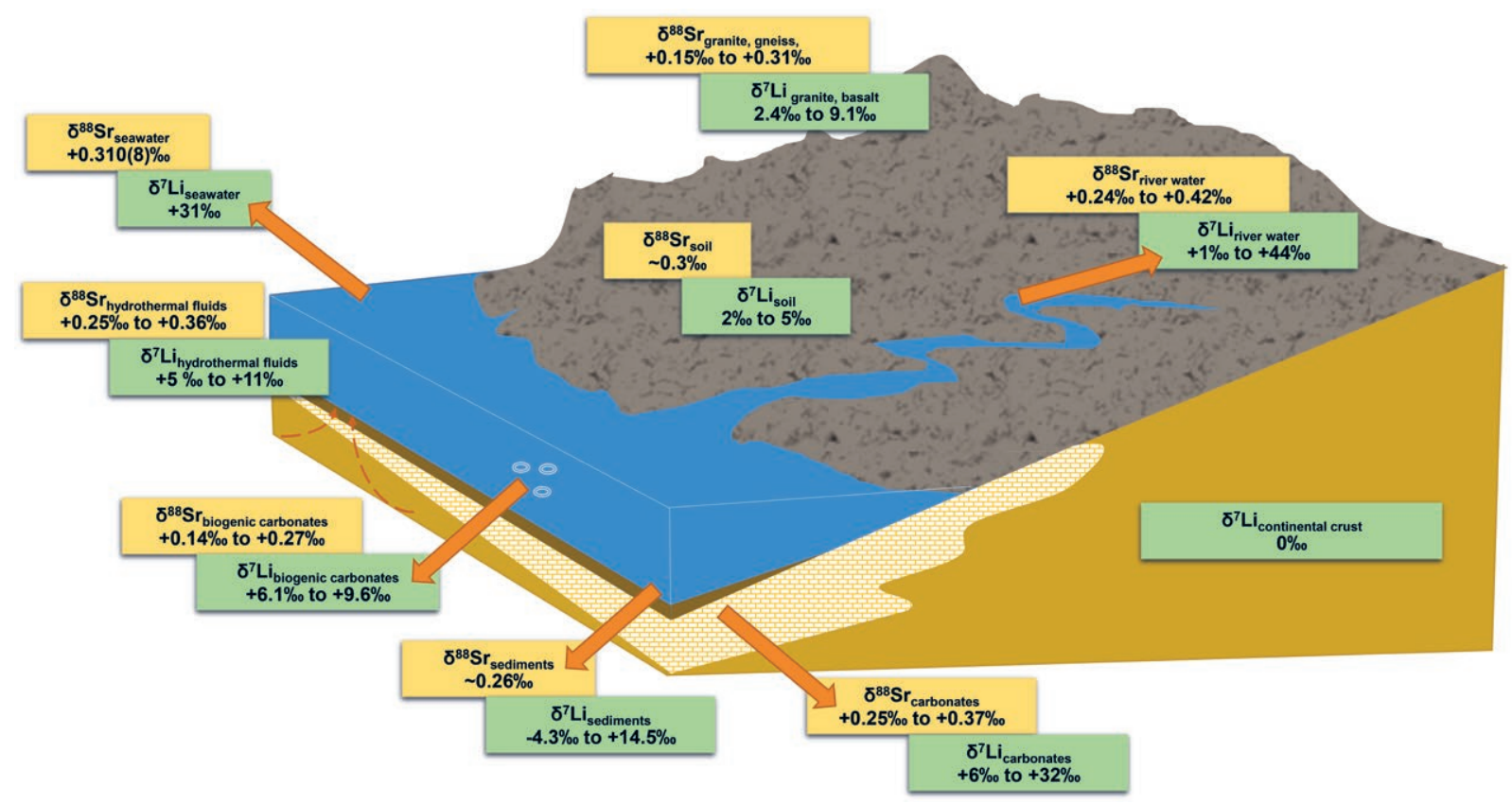

Figure 1. Schematic representation of the distribution of $\delta^{88} \mathrm{Sr}$ and $\delta^{7} \mathrm{Li}$ in different environmental compartments. 
al., 2019). In the ocean, lithium acts as a conservative element with a residence time of about one million years and a $\delta^{7} \mathrm{Li}$ isotopic signature of $+31 \%$ (PENNISTON-DORLAND et al., 2017). The steady-state is maintained by river inputs during continental weathering $(+23 \%)$, inputs by groundwater $(+15 \%)$ and hydrothermal fluids $(+7 \%)$, and the preferential removal of ${ }^{6} \mathrm{Li}$ from seawater by clay minerals (PENNISTON-DORLAND et al., 2017; and references therein); the combination of which also explains the heavier $\delta^{7} \mathrm{Li}$ signature compared to its inputs.

The prevalent incorporation of Li into silicate minerals compared to other mineral phases results in the Li isotopic signature being a promising proxy for evaluating changes related to the continental silicate weathering patterns (PISTINER \& HENDERSON, 2003; CHAN et al., 2006). In contrast to radiogenic isotopic ratios used to monitor chemical weathering, such as ${ }^{87} \mathrm{Sr} /{ }^{86} \mathrm{Sr}$, the Li isotopic composition of river water is not highly sensitive to those of the bedrock, as it mainly reflects the weathering intensity and formation of clay minerals. Thus, by combining the $\mathrm{Li}$ and $\mathrm{Sr}$ isotopic signatures of different geological environments (Fig. 1) with mineralogical data, a more complete insight into the weathering processes as well as into the cycling of these elements in the environment can be achieved.

\subsection{Diagenesis}

After deposition, sediments are subjected to diagenetic alteration, which can affect their geochemical fingerprint. The extent to which the primary sediment was altered can provide crucial information needed for the reconstruction of environmental conditions under which it was deposited (BLÄTTLER et al., 2015; CHANDA \& FANTLE, 2017; HIGGINS et al., 2018). To successfully tackle this topic, the following authors used a multi-parameter concept.

FANTLE \& HIGGINS (2014) combined the traditional approach, using elemental ratios and stable isotopes of $\mathrm{C}$ and $\mathrm{O}$, with the non-traditional, i.e. isotopic composition of $\mathrm{Ca}$ and $\mathrm{Mg}$, to assess the extent of diagenetic alteration of geochemical proxies in shallow marine carbonates from ODP (Ocean Drilling Program) Site 1196A. The results of their study suggest that the variability in $\delta^{44} \mathrm{Ca}$ (from $0.60 \%$ to $1.131 \%$ ) and $\delta^{26} \mathrm{Mg}$ (from -3.91\%o to $-2.59 \%$ ) values, along with the variations in other geochemical proxies ( $\mathrm{C}$ and $\mathrm{O}$ isotopes), can be used to elucidate diagenetic alterations, namely limestone diagenesis, and dolomitization. These authors also highlighted the importance of using several parameters when deciphering diagenetic changes in the sedimentary record.

A similar multi-proxy approach has been implemented by HIGGINS et al. (2018) in their study of early-marine diagenetic alterations and their effect on the geochemical proxies of shallowwater carbonate sediments. The authors combined measurements of the isotopic composition of $\mathrm{Ca}$ and $\mathrm{Mg}$ with other geochemical proxies $\left(\delta^{13} \mathrm{C}, \delta^{18} \mathrm{O}, \mathrm{Sr} / \mathrm{Ca}, \mathrm{Mg} / \mathrm{Ca}\right)$ and the mineralogical composition in sediments and pore fluids at ten sites in the Bahamas and the Eucla Shelf. Their study showed that variations in the isotopic composition of $\mathrm{Ca}(-1.56 \%$ to $-0.35 \%)$ and $\mathrm{Mg}(-3.46 \%$ to $-2.19 \%$ ) in the stratigraphic record were influenced by changes in the carbonate mineralogy and the type of diagenetic alteration, fluidbuffered vs. sediment-buffered diagenesis (Table 2). In the majority of the Bahamian sediments, fluid-buffered diagenetic processes combined with the transformation of aragonite and high-Mg calcite to low-Mg calcite and dolomite resulted in the coherent stratigraphic variability of $\delta^{44} \mathrm{Ca}$ values and carbonate- specific geochemical proxies, such as $\delta^{13} \mathrm{C}, \delta^{18} \mathrm{O}$, and $\mathrm{Sr} / \mathrm{Ca}$ as well as in the trace element records.

Based on previous findings (BLÄTTLER et al., 2015; CHANDA \& FANTLE, 2017), AHM et al. (2018) presented a numerical model that estimated the extent and type (fluid- vs. sediment-buffered) of early-diagenetic processes in carbonate sediments and their influence on other carbonate-specific geochemical proxies. Through tracking the elemental and isotopic composition of carbonate-bound geochemical proxies $(\mathrm{Ca}, \mathrm{Mg}, \mathrm{C}, \mathrm{O}, \mathrm{Sr} / \mathrm{Ca})$, the model proposed by these authors was able to estimate the extent of diagenetic alteration, describe the diagenetic fluid and provide more insight into the variation of geochemical proxies in ancient carbonate deposits.

Recently, LI et al. (2019) combined the $\delta^{26} \mathrm{Mg}$ isotopic signature of dolomite (ranging from $-2.28 \%$ o to $-1.78 \%$ ), with trace element analysis, the isotopic composition of $\mathrm{C}$, and $\mathrm{O}$, and mineralogical analysis to determine the dolomite formation depth in massive Cretaceous dolostones. The authors highlighted the importance of the dolomitization depth and mechanism on the $\mathrm{Mg}-\mathrm{C}$ isotope response in the sedimentary record.

Studies of modern dolomitization processes (FANTLE \& HIGGINS, 2014; BLÄTTLER et al., 2015; CHANDA \& FANTLE, 2017) show that during early diagenesis $\delta^{26} \mathrm{Mg}$ values in dolomites are controlled by porewater chemistry. Thereby, the evolutionary patterns of porewater chemistry differ in different types of early diagenetic systems due to changes in the hydrological conditions and result in stratigraphic variations in the composition of the $\mathrm{Mg}$ isotope in carbonates (AHM et al., 2018; HIGGINS et al., 2018). On the other hand, Mesozoic-Palaeozoic dolostones formed by massive dolomitization have been reported as potential archives of coeval seawater $\mathrm{Mg}$ isotope signals (HU et al., 2019). HU et al. (2019) studied the relationships between post-depositional processes and $\mathrm{Mg}$ isotope variabilities in massive dolomites by complementing magnesium isotope analyses with the analysis of $\mathrm{C}-\mathrm{O}$ isotopic composition, rare earth element (REE) concentrations and the petrographic features of dolostones. Their results indicated that different types of syndiagenetic dolomites deposited in different sedimentary settings have uniform $\delta^{26} \mathrm{Mg}$ values of $-2.06 \% \pm 0.20 \%$, implying that the chemistry of the porewater was buffered by coeval seawater during dolomitization, irrespective of sedimentary settings. Furthermore, their results suggested that post-depositional processes, including diagenetic and hydrothermal alterations, did not induce notable changes in the $\mathrm{Mg}$ isotope signals in the dolomite.

\subsection{Authigenic mineral formation}

Authigenic formation of clay minerals is another sedimentary component that significantly affects the isotope fractionation in the pore fluids.

BRADBURY \& TURCHYN (2018) used calcium isotopes to evaluate the influence of sediment type on carbonate precipitation, dissolution, and recrystallization. The analysis was performed on sediments from ODP sites 1081 and 1086, off the coast of West Africa, two geographically close sites with a different share of carbonates and organic matter. The authors combined $\mathrm{Ca}$ isotope composition of sediments $\left(\delta^{44} \mathrm{Ca}=-0.42 \% 0--0.21 \%\right.$, reported relative to Bulk Silicate Earth) with $\mathrm{Sr}$ and $\mathrm{Ca}$ concentrations in pore fluids $\left(\delta^{44} \mathrm{Ca}=-0.08-+1.04 \%\right)$ to model the rates of carbonate dissolution and precipitation. Their results suggested the occurrence of $\mathrm{Ca}$ isotope fractionation during precipitation of carbonate. 
BLÄTTLER et al. (2015) on the other hand, used $\mathrm{Mg}$ and $\mathrm{Ca}$ isotopes as geochemical tracers for authigenic carbonate formation in marine sediments of Miocene age. Similarly to FANTLE \& HIGGINS (2014), the authors combined measurements of $\delta^{26} \mathrm{Mg}$ and $\delta^{44} \mathrm{Ca}$ (delta values of $\mathrm{Ca}$ are reported relative to modern seawater), with those of $\delta^{13} \mathrm{C}$ and $\delta^{18} \mathrm{O}$, performing a multiisotope study on authigenic dolomites occurring as beds and nodules within the stratigraphic sequence of the Monterey Formation, offshore California. Their data suggested that the obtained isotopic signature of $\mathrm{Mg}$ and $\mathrm{Ca}$ point to dolomite precipitation and carbonate recrystallization, respectively. There, the variability of $\delta^{26} \mathrm{Mg}$ (from $-2.86 \%$ to $-0.52 \%$ ) and $\delta^{44} \mathrm{Ca}$ values (from $-1.10 \%$ o to $-0.35 \%$ ) with stratigraphic depth, and anti-correlation of $\mathrm{Mg}$ and $\mathrm{Ca}$ isotopes, was related to early-diagenetic processes in the sedimentary pore fluid. The large variation of $\delta^{13} \mathrm{C}$ values in dolomite on the other hand, was attributed to its formation in zones of bacterial sulfate reduction or methanogenesis.

KIMMIG \& HOLMDEN (2017) investigated the potential of $\mathrm{Mg}$ isotopes, combined with other geochemical proxies ( $\mathrm{Sr} / \mathrm{Ca}$ and $\mathrm{Ca} / \mathrm{Mg}$ ratios, $\delta{ }^{13} \mathrm{C}$, mineralogy) to identify changes in carbonate polymorph mineralogy in a carbonate mud deposit marked by the Hirnatian glaciation. Their results showed that in the investigated section, during the glaciation event, a 2-3\% increase in sedimentary $\delta^{26} \mathrm{Mg}$ values occurred. The changes in the abundance of dolomite in the host limestone were considered responsible for the observed shifts in $\delta^{26} \mathrm{Mg}$, which was also in agreement with other geochemical proxies and indicators of sea-level changes. According to the trends observed for the $\delta^{26} \mathrm{Mg}$ and $\mathrm{Ca} / \mathrm{Mg}$ ratios, changes in carbonate mineralogy (e.g. variations in the abundance of aragonite) induced the following changes in the $\delta^{26} \mathrm{Mg}$ isotopic composition of limestone: $-4.45 \pm 0.82 \%$ o before glaciation, $-2.54 \pm 0.23 \%$ o during glaciation and $-3.05 \pm 0.27 \%$ o after glaciation. This exemplifies the potential of a multi-proxy approach in the identification of changes in carbonate polymorphs in sedimentary records.

\subsection{Adsorption-desorption processes}

While carbonates preferentially incorporate light $\mathrm{Mg}$ and $\mathrm{Ca}$ isotopes (FANTLE \& HIGGINS, 2014; BLÄTTLER et al., 2015; KIMMIG \& HOLMDEN, 2017; HIGGINS et al., 2018), limestone diagenesis and dolomitization cause their shift towards lower or higher values, respectively (Table 2). In contrast to carbonates, clay minerals display heavier $\delta^{26} \mathrm{Mg}$ values $(-1.82 \%$ o to $+0.18 \%$; WIMPENNY et al., 2014), but also to some extent variable ones, depending on the share of the exchangeable and the structurally incorporated $\mathrm{Mg}$. Similar to magnesium, the calcium isotope composition of pore waters was also found to be influenced by the adsorption/desorption processes of $\mathrm{Ca}^{2+}$ from the surfaces of clay minerals (OCKERT et al., 2013). OCKERT et al. (2013) investigated the influence of cation exchange between different clay minerals (montmorillonite, illite, and kaolinite) and marine sediment, with $\mathrm{Ca}$ in artificial seawater. The authors found that in the marine porewater environment the light Ca preferentially adsorbs onto clay minerals with the fractionation between the adsorbed and the dissolved $\mathrm{Ca}^{2+}$ and $\delta^{44} \mathrm{Ca}$ varying between $+0.09 \%$ and $-2.76 \%$. Their results also suggested a mineral specific fractionation of $\mathrm{Ca}$, where kaolinite $(-1.2 \%$ and $-2.76 \%$ during adsorption and desorption, respectively) and illite (-0.82\%o and $-1.2 \%$ during adsorption and desorption, respectively), showed more significant fractionation compared to montmorillonite. Also, the presence of ammonium, originating from organic matter decomposition, was considered to cause desorption of $\mathrm{Ca}^{2+}$ from the clay mineral surfaces into the pore water. This topic was further studied by BRAZIER et al. (2019) who experimentally showed that the intensity of $\mathrm{Ca}$ isotopic fractionation during adsorption onto clay minerals is controlled by their structural characteristics, including layer charge, specific surface area, and interlayer space. The results obtained by these authors highlighted the importance of adsorption-desorption processes involving mineral particles in the assessment of $\mathrm{Ca}$ isotopic signatures in natural environments. The more so as, in addition to carbonates, silicate minerals are the second dominant source of $\mathrm{Ca}$ and $\mathrm{Mg}$ in rivers, and therefore seawater, and discerning the key controls of $\mathrm{Ca}$ and $\mathrm{Mg}$ isotopic composition during the alteration of primary silicates and formation of alteration phases such as clay minerals can help in understanding how these elements behave during weathering.

\section{NON-TRADITIONAL ISOTOPES AS INDICATORS OF ENVIRONMENTAL CONDITIONS}

\subsection{Redox conditions}

The chromium isotope system functions as an atmospheric redox proxy because oxidative weathering of crustal $\mathrm{Cr}$ (III)-bearing minerals results in the release of ${ }^{53} \mathrm{Cr}$-enriched mobile $\mathrm{Cr}(\mathrm{VI})$ to the solution (GILLEAUDEAU et al., 2016). $\mathrm{Cr}(\mathrm{VI})$ is then carried to the oceans via rivers, thus imparting a positively fractionated $\delta^{53} \mathrm{Cr}$ signal to modern seawater $(\sim 0.5 \pm 0.1 \%$ ) (BONNAND et al., 2013) compared to crustal values $(-0.123 \pm 0.102 \%$ o) (SCHOENBERG et al., 2008). In marine environments, chromium has a tendency to co-precipitate with different mineral phases and readily accumulates in sediments in reducing conditions (e.g. GILLEAUDEAU et al., 2016; Fig. 2), which makes $\delta^{53} \mathrm{Cr}$ a valuable redox proxy not only in palaeo-environmental studies but also in recent marine settings (BONNAND et al., 2013; SCHEIDERICH et al., 2015; GILLEAUDEAU et al., 2016).

According to SCHEIDERICH et al. (2015), modern surface seawater is heterogeneous in $\delta^{53} \mathrm{Cr}$, with isotopic heterogeneity confined to the surface water (from $0.41 \%$ to $1.51 \%$ in the Atlantic ocean, and from $0.91 \%$ to $1.43 \%$ in the Pacific ocean; SCHEIDERICH et al., 2015), while the deep-water masses in the Atlantic and Pacific displayed similar $\delta^{53} \mathrm{Cr}$ values $(\sim 0.5 \%$, SCHEIDERICH et al., 2015); Table 3). In contrast, the study of BRUGGMANN et al. (2019) on chromium isotope cycling in the water column and sediments of the Peruvian continental margin, a modern oxygen minimum zone (OMZ) in an open marine setting, yielded somewhat different values. Their results show $\delta^{53} \mathrm{Cr}$ ranging from $0.02 \pm 0.16 \%$ to $0.59 \pm 0.11 \%$ and from $0.31 \pm 0.07 \%$ to $0.92 \pm 0.12 \%$ in seawater and sediments, respectively. The sediments deposited in permanently anoxic waters showed $\delta^{53} \mathrm{Cr}$ at $0.77 \pm 0.19 \%$, while those deposited in oxic bottom waters were characterized by $\delta^{53} \mathrm{Cr}$ at $0.46 \pm 0.19 \%$, suggesting that sediment $\mathrm{Cr}$ concentrations and $\delta^{53} \mathrm{Cr}$ values are influenced by water column redox (e.g. reductive dissolution and transport of Fe-oxides) and/or early diagenetic processes (e.g. redistribution of Cr during phosphogenesis). Although both mentioned studies emphasize the importance of redox conditions for $\mathrm{Cr}$ fractionation in marine environments, little is known about redox cycling of $\mathrm{Cr}$ within the water column, changes across the sediment-water interface, and the exact mechanisms by which $\mathrm{Cr}$ is incorporated into marine sediments, which remain poorly constrained (SCHEIDERICH et al., 2015; BRUGGMANN et al., 2019). All of this is important as most of the studies conducted have neglected the internal fractionation processes in the marine $\mathrm{Cr}$ cycle, such 
Table 2. Magnesium and calcium isotope composition in different types of samples.

\begin{tabular}{|c|c|c|c|}
\hline Isotope & $\delta$ & Sample type & Reference \\
\hline \multirow{21}{*}{$\delta^{26} \mathrm{Mg}$} & $-2.86 \%$ o to $-0.52 \%$ o & bulk dolomite & BLÄTTLER et al., 2015 \\
\hline & $-2.54 \% \circ \pm 0.23 \% \circ$ & calcite & KIMMIG \& HOLMDEN, 2017 \\
\hline & $+0.18 \% 0$ & illite & WIMPENNY et al., 2014 \\
\hline & $-0.30 \%$ & montmorillonite & WIMPENNY et al., 2014 \\
\hline & $-1.82 \% 0$ & kaolinite & WIMPENNY et al., 2014 \\
\hline & $-3.46 \%$ o to $-2.19 \%$ o & Great Bahama Bank & HIGGINS et al., 2018 \\
\hline & $-3.02 \%$ o to $-2.64 \%$ o & Little Bahama Bank & HIGGINS et al., 2018 \\
\hline & $-3.13 \%$ o to $-3.07 \%$ & bank-top sediment & HIGGINS et al., 2018 \\
\hline & $-3.26 \%$ o to $-2.62 \%$ o & Eucla Shelf & HIGGINS et al., 2018 \\
\hline & $-0.72 \%$ o to $-0.39 \%$ o & pore water & CHANDA \& FANTLE, 2017 \\
\hline & $-5.00 \%$ o to $-2.23 \%$ o & bulk carbonates & CHANDA \& FANTLE, 2017 \\
\hline & $-3.91 \%$ o to $-2.59 \%$ o & bulk carbonate & FANTLE \& HIGGINS, 2014 \\
\hline & $-3.60 \%$ $\pm 0.25 \%$ & limestone, average & FANTLE \& HIGGINS, 2014 \\
\hline & $-2.68 \% 0 \pm 0.07 \%$ & dolostone, average & FANTLE \& HIGGINS, 2014 \\
\hline & $-2.28 \%$ o to $-1.78 \%$ o & dolostone & Ll et al., 2019 \\
\hline & $-2.29 \% \circ \pm 0.10 \%$ & dolostone & GALY et al., 2002 \\
\hline & $-2.06 \% \circ \pm 0.20 \% \circ$ & syndiagenetic dolomite & HU et al., 2019 \\
\hline & $-0.22 \% 0 \pm 0.10 \%$ & UCC & Ll et al., 2010 \\
\hline & $-0.63 \%$ o to $0.64 \%$ & Iceland rivers & POGGE VON STRANDMANN et al., 2008 \\
\hline & $0.85 \%$ & hydrothermal springs & POGGE VON STRANDMANN et al., 2008 \\
\hline & $-0.83 \%$ o & ice & POGGE VON STRANDMANN et al., 2008 \\
\hline \multirow{12}{*}{$\delta^{44} \mathrm{Ca}$} & $-1.10 \%$ o to $-0.35 \%$ o & bulk dolomite & BLÄTTLER et al., 2015 \\
\hline & $-1.56 \%$ o to $-0.40 \%$ o & Great Bahama Bank & HIGGINS et al., 2018 \\
\hline & $-0.68 \%$ o to $-0.35 \%$ o & Little Bahama Bank & HIGGINS et al., 2018 \\
\hline & $-1.49 \%$ o to $-1.20 \%$ o & bank-top sediment & HIGGINS et al., 2018 \\
\hline & $-1.24 \%$ o to $-0.88 \%$ o & Eucla Shelf & HIGGINS et al., 2018 \\
\hline & $0.60 \%$ o to $1.131 \%$ o & bulk carbonate & FANTLE \& HIGGINS, 2014 \\
\hline & $0.97 \% \circ \pm 0.24 \% \circ$ & limestone, average & FANTLE \& HIGGINS, 2014 \\
\hline & $1.03 \%$ $\pm 0.15 \%$ & dolostone, average & FANTLE \& HIGGINS, 2014 \\
\hline & $-0.08 \%$ o to $1.04 \%$ o & pore fluid Site 1081 & BRADBURY \& TURCHYN, 2018 \\
\hline & $-0.42 \%$ o to $-0.21 \%$ o & sediment Site 1081 & BRADBURY \& TURCHYN, 2018 \\
\hline & $0.11 \%$ o to $0.78 \%$ o & pore fluid Site 1086 & BRADBURY \& TURCHYN, 2018 \\
\hline & $-0.42 \%$ o to $-0.25 \%$ o & sediment Site 1086 & BRADBURY \& TURCHYN, 2018 \\
\hline
\end{tabular}

as the export of lighter $\mathrm{Cr}(\mathrm{III})$ with organic matter into the sediment (SEMENIUK et al., 2016).

The isotopic composition of $\mathrm{Ni}$ can also be used (Fig. 2) in elucidating the redox processes in sediments. Namely, its co-pre- cipitation with $\mathrm{Fe}-\mathrm{Mn}$ oxides represents an important output from the dissolved pool in an oxygenated environment (e.g., GALL et al., 2013; CAMERON \& VANCE, 2014; TENG et al., 2017; Table 3). In reducing conditions, however, Ni shows a prefe-

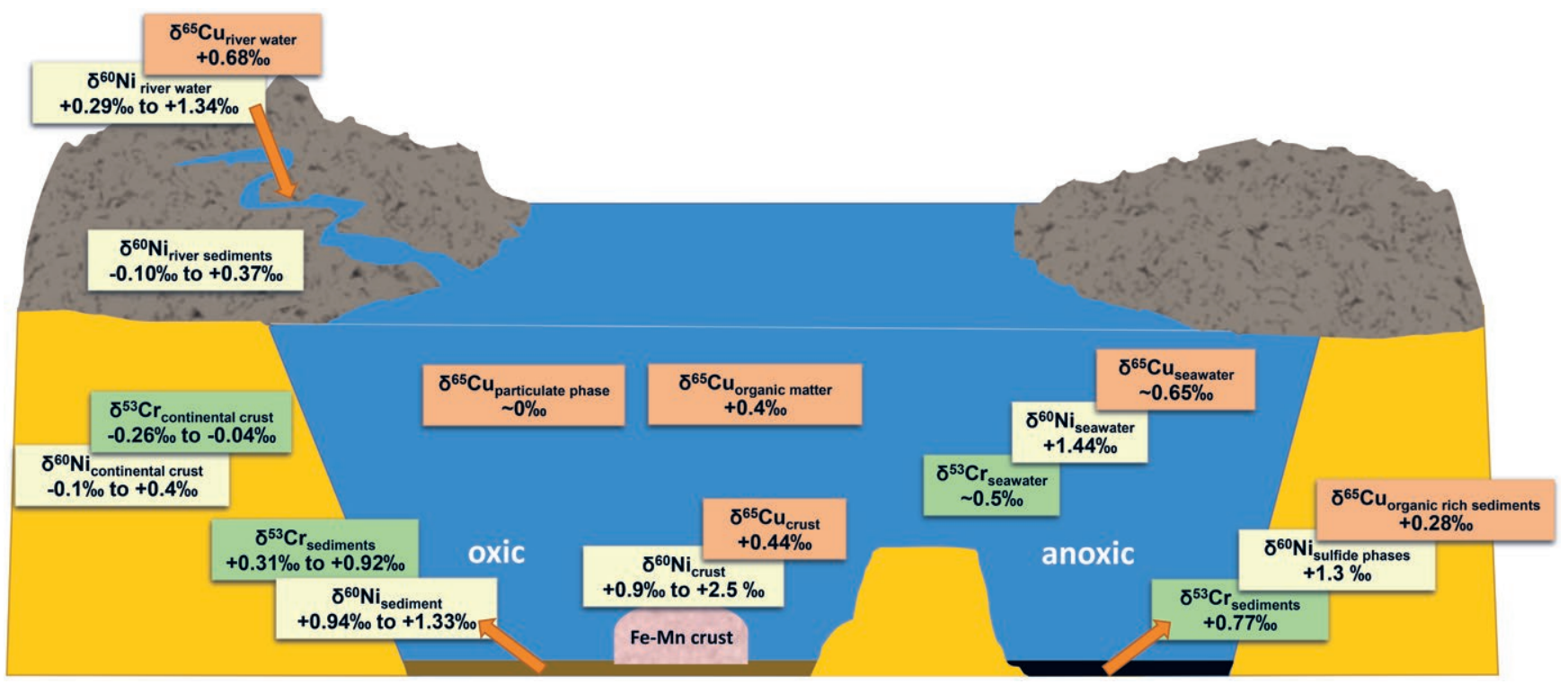

Figure 2. Schematic representation of the distribution of $\delta^{53} \mathrm{Cr}, \delta^{60} \mathrm{Ni}$ and $\delta^{65} \mathrm{Cu}$ in different environmental compartments. 
Table 3. Chromium, nickel and copper isotope composition in different types of samples.

\begin{tabular}{|c|c|c|c|}
\hline Isotope & $\delta$ & Sample type & Reference \\
\hline \multirow{10}{*}{$\delta^{53} \mathrm{Cr}$} & $-0.26 \%$ o to $-0.04 \%$ o & continental crust & SCHOENBERG et al., 2008 \\
\hline & $\sim 0.5 \pm 0.1 \%$ & modern seawater & BONNAND et al., 2013 \\
\hline & $+0.65 \%$ o to $+0.76 \%$ o & Bahamian and Yucatan ooid & BONNAND et al., 2013 \\
\hline & $+0.41 \%$ o to $+1.51 \%$ o & Atlantic Ocean water & SCHEIDERICH et al., 2015 \\
\hline & $+0.61 \%$ o to $+1.43 \%$ o & Pacific Ocean water & SCHEIDERICH et al., 2015 \\
\hline & $+0.99 \%$ o to $+1.55 \%$ o & Arctic seawater & SCHEIDERICH et al., 2015 \\
\hline & $+0.02 \%$ o to $+0.59 \%$ o & seawater & BRUGGMANN et al., 2019 \\
\hline & $+0.31 \%$ o to $+0.92 \%$ o & recent sediments & BRUGGMANN et al., 2019 \\
\hline & $0.46 \pm 0.19 \%$ & sediments deposited in oxic conditions & BRUGGMANN et al., 2019 \\
\hline & $0.77 \pm 0.19 \%$ & sediments deposited in anoxic conditions & BRUGGMANN et al., 2019 \\
\hline \multirow{15}{*}{$\delta^{60} \mathrm{Ni}$} & $+0.9 \%$ to $+2.5 \%$ & Fe-Mn crusts & GALL et al., 2013 \\
\hline & $+1.79 \%$ $\pm 0.21 \%$ & North Pacific Fe-Mn crust & Ll et al., 2019 \\
\hline & $+1.73 \% \circ \pm 0.21 \% 0$ & South Pacific Fe-Mn crust & Ll et al., 2019 \\
\hline & $+1.3 \% 0 \pm 0.7 \%$ & Atlantic Ocean Fe-Mn crust & GALL et al., 2013 \\
\hline & $+1.7 \% 0 \pm 0.8 \% \circ$ & Pacific Ocean Fe-Mn crust & GALL et al., 2013 \\
\hline & $+1.6 \% \circ \pm 0.3 \%$ & Indian Ocean Fe-Mn crust & GALL et al., 2013 \\
\hline & $+0.94 \%$ o to $+1.33 \%$ o & sediment & CISCATO et al., 2018 \\
\hline & $+0.86 \%$ to $+1.83 \%$ o & organic matter and associated pyrite fraction & CISCATO et al., 2018 \\
\hline & $+0.86 \%$ and $+1.37 \% 0$ & HF-dissolvable sediment fraction & CISCATO et al., 2018 \\
\hline & $+1.3 \pm 0.4 \%$ & sulfide phases & CISCATO et al., 2018 \\
\hline & $+0.15 \% \pm \pm 0.24 \%$ & terrestrial samples (mantle and crust) & CAMERON et al., 2009 \\
\hline & $+1.19 \%$ o to $1.47 \%$ o & deep ocean water & CAMERON and VANCE, 2014 \\
\hline & $+1.44 \%$ $\pm 0.15 \% \circ$ & seawater & CAMERON and VANCE, 2014 \\
\hline & $+0.29 \%$ o to $+1.34 \%$ o & river water & CAMERON and VANCE, 2014 \\
\hline & $+0.14 \% \circ \pm 0.23 \% \circ$ & river sediments & CAMERON and VANCE, 2014 \\
\hline \multirow{12}{*}{$\delta^{65} \mathrm{Cu}$} & $+0.65 \% \circ \pm 0.08 \% 0$ & Indian and Pacific Ocean deep water & TAKANO et al., 2014 \\
\hline & $+0.70 \%$ $\pm 0.11 \% \circ$ & Tasman Sea deep water & THOMPSON et al., 2014 \\
\hline & $+0.51 \% \circ \pm 0.20 \%$ & Mediterranean Sea & BACONNAIS et al., 2018 \\
\hline & $+0.08 \% \circ \pm 0.17 \%$ & lithogenic fraction & MOYNIER et al., 2017 \\
\hline & $+0.31 \% \circ \pm 0.11 \%$ & bioauthigenic fraction & LITTLE et al., 2017 \\
\hline & $+0.44 \% 0 \pm 0.23 \% \circ$ & Fe-Mn crusts and nodules & LITTLE et al., 2014 \\
\hline & $+0.68 \%$ & river water & LITTLE et al., 2018 \\
\hline & $+0.11 \% \circ \pm 0.09 \%$ & lithogenic part of particulate phase & LITTLE et al., 2018 \\
\hline & $+0.40 \%$ $\pm 0.10 \%$ & labile fraction of particulate phase & LITTLE et al., 2018 \\
\hline & $+0.10 \%$ o to $+0.35 \%$ o & marine particles & MARÉCHAL et al., 1999 \\
\hline & $+0.03 \%$ o to $+0.52 \%$ o & marine particles & THOMPSON et al., 2014 \\
\hline & $+0.08 \% \circ \pm 0.17 \%$ & lithogenic fraction, average & MOYNIER et al., 2017 \\
\hline
\end{tabular}

rence towards dissolved sulfide (e.g., CISCATO et al., 2018) and is either scavenged by reactive sulfide species or sulfide precipitation. While the Fe-Mn oxides show preference to isotopically heavier isotopes $(+0.9 \%$ to $+2.5 \%$, GALL et al., 2013$)$, sulfide phases prefer the isotopically lighter $\mathrm{Ni}(+1.3 \pm 0.4 \%$, CISCATO et al., 2018).

\subsection{Organic matter}

In addition to co-precipitation with Fe-Mn-oxyhydroxides or sulfide phases, depending on the redox state, two other important processes control the marine geochemistry of $\mathrm{Ni}$ and its isotope fractionation; biological cycling via cell uptake and the burial of organics (CAMERON et al., 2009; CAMERON \& VANCE, 2014). However, sedimentary outputs that control the heavy $\delta^{60} \mathrm{Ni}$ content of the ocean are at odds with the lighter Ni stable isotope composition of the inputs, by $1.3 \%$ to $1.7 \%$ (CISCATO et al.,
2018), a feature common to many other transition metals (e.g. LITTLE et al., 2014) (Fig. 2). To find a possible explanation for this imbalance, CISCATO et al. (2018) investigated upwelling margin sediments and found that the organic-rich sediments beneath upwelling zones are also an important output flux of $\mathrm{Ni}$ from the oceans. However, they found that the $\delta^{60} \mathrm{Ni}$ in sediments $\left(+0.94 \%\right.$ to $+1.33 \%$ ) was almost identical to the $\delta^{60} \mathrm{Ni}$ of modern seawater $(+1.19 \%$ to $+1.47 \%$ ) (CAMERON \& VANCE, 2014). Despite this similarity, the approach they adopted, by analyzing the $\mathrm{Ni}$ isotopic signature of both fractions, the organic-sulfides (with $\delta^{60} \mathrm{Ni}$ from $+0.86 \%$ to $+1.83 \%$ ) and the HF-digestible fraction (with $\delta^{60} \mathrm{Ni}$ from $+0.86 \%$ and $+1.37 \%$ ), has the potential to quantify isotope fractionations associated with biological uptake as well as to record the $\delta^{60} \mathrm{Ni}$ of the contemporary seawater.

Even though $\mathrm{Cr}$ is not considered bio-essential, organic matter can also significantly influence the $\mathrm{Cr}$ cycle (e.g. SEMENIUK 
et al., 2016) and $\mathrm{Cr}$ (III) can be removed from seawater by phytoplankton via adsorption or incorporation, both of which may cause isotope fractionations induced by the initial reduction of Cr(VI) to Cr(III) (SEMENIUK et al., 2016).

The stable isotopic signature of copper also has the potential to provide significant information on the biogeochemical cycling of this element in the environment (MOYNIER et al., 2017). Similar to chromium, redox transformations between $\mathrm{Cu}(\mathrm{I})$ and $\mathrm{Cu}(\mathrm{II})$ species are the main processes in natural systems resulting in $\mathrm{Cu}$ isotope fractionation (LITTLE et al., 2014; 2017), e.g., reduced and precipitated $\mathrm{Cu}(\mathrm{I})$ species are known to be lighter by $2 \%$ to $5 \%$ relative to dissolved $\mathrm{Cu}$ (II) species (RYAN et al., 2014). The fractionation between organically complexed and free inorganic species, ranging from $+0.1 \%$ and $+0.8 \%$ o (RYAN et al., 2014), suggests that complexation by soluble ligands in natural waters further induces significant isotope fractionation of $\mathrm{Cu}$. In seawater, $99.9 \%$ of dissolved $\mathrm{Cu}$ is organically complexed, whereby complexation of $\mathrm{Cu}$ with $\mathrm{OM}$ favours retention of the heavy isotope in solution (VANCE et al., 2008). The organic matter $(\mathrm{OM})$ is thus considered to be a key variable controlling $\mathrm{Cu}$ speciation in both terrestrial and aquatic environments.

\section{NON-TRADITIONAL ISOTOPES AS A TOOL FOR DECIPHERING MULTIPLE SOURCES CONTRIBUTION}

By combining data on partitioning and the isotopic fractionation of transition metals between different phases in both terrestrial and aquatic systems, (e.g. between oxides, sulfides or organic matter, or dissolved vs. particulate; Table 3; Fig. 2), the contribution of the different sources can be differentiated. LITTLE et al. (2018) studied $\mathrm{Cu}$ isotope distributions in the dissolved and particulate phase in the South Atlantic. Their observations point to the existence of two pools of $\mathrm{Cu}$ isotopes in the particulate phase, a refractory pool with a lithogenic $\delta^{65} \mathrm{Cu}$ signature (at about $0 \%$ ) and a labile pool, associated with organic matter, at about $+0.4 \%$ o (Table 3). According to their data, the labile pool is isotopically lighter compared to the homogeneous deep ocean dissolved pool at about $+0.7 \%$ o (VANCE et al., 2008; RYAN et al., 2014).

Although the ocean interior is considered to have a very homogeneous $\mathrm{Cu}$ isotope composition at about $+0.65 \%$ o $(+0.66 \pm$ $0.07 \%$ at depths $>200 \mathrm{~m}$ in the South Atlantic; LITTLE et al., 2018 ); $+0.65 \pm 0.07 \%$ o, $>200 \mathrm{~m}$ in the North Atlantic (BOYLE et al., 2012); $+0.65 \pm 0.08 \%$ o, $>200 \mathrm{~m}$ in the Indian and Pacific Oceans (TAKANO et al., 2014); $+0.70 \pm 0.11 \%$, $>200 \mathrm{~m}$ in the Tasman Sea (THOMPSON et al., 2014); and $+0.51 \%$ $\pm 0.20 \%$, in the Mediterranean Sea (BACONNAIS et al., 2018), deviations towards lower $\delta^{65} \mathrm{Cu}$ values have been reported for the upper water column (between $+0.41 \%$ ond $0.49 \%$ ), and towards higher $\delta^{65} \mathrm{Cu}$ values in the deeper parts of the water column (between $+0.75 \%$ and $0.84 \%$ ) (MOYNIER et al., 2017) and reference therein). This variation in isotopic composition along the depth profiles can be attributed to biological activity, aerosol deposition, and local supply (LITTLE et al., 2018). Despite this variability, the $\mathrm{Cu}$ isotope composition of seawater is similar to the riverine input value of $+0.68 \%$ and to the calculated combined riverine and atmospheric $\mathrm{Cu}$ source of $+0.63 \%$, which is substantially higher compared to the upper continental crust (UCC) at $+0.08 \pm 0.17 \%$ o (MOYNIER et al., 2017). Similar to Ni, only two major sinks have been identified so far for $\mathrm{Cu}$, Fe-Mn crusts and nodules and organic-rich sediments, and both of them display a preference for lighter $\mathrm{Cu}$ isotopes, at $+0.44 \%$ (LITTLE et al., 2014) and $+0.28 \%$ (LITTLE et al., 2017), respectively. The discrepancy between the light isotope signature of sinks and the heavy isotope signature of the major inputs by rivers requires identification of the additional light source(s) or heavy $\operatorname{sink}(\mathrm{s})$.

The role of ferromanganese crusts as archives for deep-water $\mathrm{Ni}$ isotope compositions was studied by GUEGUEN et al. (2016) and GALL et al. (2013). GUEGUEN et al. (2016) showed that despite different growth rates, textures and geochemical patterns, Fe-Mn crusts from both the North and South Pacific Oceans have had homogenous Ni isotope compositions over the last $17 \mathrm{Ma}$, yielding average $\delta^{60} \mathrm{Ni}$ values of $1.79 \pm 0.21 \%$ and $1.73 \pm 0.21 \%$, respectively. Results of GALL et al. (2013) suggested that the heavy Ni isotopic signature of crusts $(+0.9 \%$ to $+2.5 \%$ ) reflects the input to the ocean from continental weathering and possibly also from hydrothermal fluids. Despite significant variation in the $\mathrm{Ni}$ isotopic composition of surface scrapings of Fe-Mn crusts, they observed low $\delta^{60} \mathrm{Ni}$ variability in different layers of crust from the central Pacific Ocean that started growing over $70 \mathrm{Ma}$, suggesting that oceanic sources and sinks largely remained in steady-state over the Cenozoic. Still, the $\delta^{60} \mathrm{Ni}$ values reported by GALL et al. (2013) are both heavier and lighter than the modern seawater value determined by CAMERON \& VANCE (2014), at $1.44 \pm 0.15 \%$. Moreover, nickel isotope depth profile s in water columns of the Pacific, Atlantic, and Southern Oceans studied by CAMERON \& VANCE (2014) showed no variations, suggesting that $\mathrm{Ni}$ isotopes are homogenous in deep waters. At steady-state, the $\mathrm{Ni}$ isotope composition of seawater is thus controlled by the relative fluxes of $\mathrm{Ni}$ inputs to the ocean (e.g. rivers, atmospheric deposits, hydrothermal sources) and Ni uptake (e.g. authigenic sinks, organic matter burial) (GUEGUEN et al., 2016). Since the riverine flux and the scavenging of $\mathrm{Ni}$ by Fe-Mn oxides are, respectively, the main input and output fluxes for this element in the ocean (GALL et al., 2013; CAMERON \& VANCE, 2014), GUEGUEN et al. (2016) proposed that the modern marine Ni isotope mass balance is controlled by the isotopic composition of these fluxes. Although the mechanisms that control the $\mathrm{Cu}$ and $\mathrm{Ni}$ isotope fractionation in seawater are still not well understood, their $\delta^{65} \mathrm{Cu}$ and $\delta^{60} \mathrm{Ni}$ isotopic signatures have the potential to distinguish the contribution of different phases to the sediments and when combined with seawater records could provide some new insights into their cycling in both modern and ancient environments. However, to further understand these processes it is necessary to gather a larger dataset of $\delta^{65} \mathrm{Cu}$ and $\delta^{60} \mathrm{Ni}$ encompassing several sources and sinks, as well as different oceanic water masses and contrasting biogeochemical domains.

\section{CONCLUSION}

From the above, it is evident that the development of new techniques not only provided answers to existing questions but also opened new topics and created new challenges. However, it is also increasingly clear that a complete and proper interpretation of the various processes during the geological past requires a multiproxy approach. The above-listed elements and their isotope signatures have the potential to explain a number of processes in both recent and palaeo-environments (e.g. redox conditions, the influence of organic matter, recrystallization, diagenesis, weathering, contribution of sources, etc.). Combining such information with additional geochemical and mineralogical data will certainly ensure their more complete and correct interpretation.

The lack of data is currently a limiting factor and calls for new studies that will expand our knowledge on non-traditional isotope signatures and provide new insights into many yet-unresolved geological problems. 


\section{ACKNOWLEDGEMENT}

The authors would like to acknowledge the valuable contributions of the anonymous reviewers and editors.

Funding: This research received no external funding.

Conflicts of Interest: The authors declare no conflict of interest.

\section{REFERENCES}

AHM, A.S.C., BJERRUM, C.J., BLÄTTLER, C.L., SWART, P.K. \& HIGGINS, J.A (2018): Quantifying early marine diagenesis in shallow-water carbonate sediments.- Geochim. Cosmochim. Acta, 236, 140-159. doi: 10.1016/j. gca.2018.02.042

ANDREWS, M.G., JACOBSON, A.D., LEH, G.O., HORTON, T.W. \& CRAW, D. (2016): Radiogenic and stable $\mathrm{Sr}$ isotope ratios $\left({ }^{87} \mathrm{Sr} /{ }^{86} \mathrm{Sr}, \delta^{88} / 86 \mathrm{Sr}\right)$ as tracers of riverine cation sources and biogeochemical cycling in the Milford Sound region of Fiordland New Zealand. isotopes as palaeoceanographic tracers.- Geochim. Cosmochim. Acta, 173, 284-303. doi: 10.1016/j.gca.2015.10.005

BACONNAIS, I., ROUXEL, O., DULAQUAIS, G. \& BOYE, M. (2018): Determination of the copper isotope composition of seawater revisited: A case study from the Mediterranean Sea.- Chem. Geol., 511, 465-480. doi: 10.1016/j. chemgeo.2018.09.009

BLÄTTLER, C.L., MILLER, N.R. \& HIGGINS, J.A. (2015): Mg and Ca isotope signatures of authigenic dolomite in siliceous deep-sea sediments.- Earth Planet. Sc. Lett., 419, 32-42. doi: 10.1016/j.eps1.2015.03.006

BÖHM, F., GUSSONE, N., EISENHAUER, A., DULLO, W.C., REYNAUD, S. \& PAYTAN, A. (2006): Calcium isotope fractionation in modern scleractinian corals.- Geochim. Cosmochim. Acta, 70/17, 4452-4462. doi: 10.1016/j. gca.2006.06.1546

BONNAND, P., JAMES, R.H., PARKINSON, I.J., CONNELLY, D.P. \& FAIRCHILD, I.J. (2013). The chromium isotopic composition of seawater and marine carbonates.- Earth Planet Sc. Lett., 382, 10-20. doi: 10.1016/j.eps1.2013.09.001

BOYLE, E.A., JOHN, S., ABOUCHAMI, W., ADKINS, J.F., ECHEGOYEN-SANZ, Y. et al. (2012): GEOTRACES IC1 (BATS) contamination-prone trace element isotopes $\mathrm{Cd} \mathrm{Fe} \mathrm{Pb} \mathrm{Zn} \mathrm{Cu}$ and Mo intercalibration.- Limnol. Oceanogr. Meth., 10, 653-665. doi: 10.4319/lom.2012.10.653

BRADBURY, H.J. \& TURCHYN, A.V. (2018): Calcium isotope fractionation in sedimentary pore fluids from ODP Leg 175: Resolving carbonate recrystallization.Geochim. Cosmochim. Acta, 236, 121-139. doi: 10.1016/j.gca.2018.01.040

BRAND, W.A., COPLEN, T.B., VOGL, J., ROSNER, M. \& PROHASKA, T. (2014): Assessment of international reference materials for isotope-ratio analysis (IUPAC Technical Report).- Pure Appl. Chem., 86/3, 425-467. doi: 10.1515/pac-20131023

COPLEN, T.B. (2011): Guidelines and recommended terms for expression of stable-isotope-ratio and gas-ratio measurement results.- Rapid Commun. Mass Spectrom., 25, 2538-2560. doi: 10.1002/rcm.5129

BRAZIER, J.-M., SCHMITT, A.-D., GANGLOFF, S., PELT, E., CHABAUX, F. \& TERTRE, E. (2019): Calcium isotopic fractionation during adsorption onto and desorption from soil phyllosilicates (kaolinite montmorillonite and muscovite).Geochim. Cosmochim. Acta, 250, 324-347. doi: 10.1016/j.gca.2019.02.017

BRUGGMANN, S., SCHOLZ, F., KLAEBE, R.M., CANFIELD, D.E. \& FREI, R. (2019): Chromium isotope cycling in the water column and sediments of the Peruvian continental margin.- Geochim. Cosmochim. Acta, 257, 224-242. doi: 10.1016/j.gca.2019.05.001

CAMERON, V. \& VANCE, D. (2014): Heavy nickel isotope compositions in rivers and the oceans.- Geochim. Cosmochim. Acta., 128, 195-211. doi: 10.1016/j. gca.2013.12.007

CAMERON, V., VANCE, D., ARCHER, C. \& HOUSE, C.H. (2009). A biomarker based on the stable isotopes of nickel.- P. Natl. Acad. Sci. USA, 106/27, 10944-10948. doi: 10.1073/pnas.0900726106

CHAN, L.H., LEEMAN, W.P. \& PLANK, T. (2006): Lithium isotopic composition of marine sediments.- Geochem. Geophys. Geosy., 7/6, 1-25. doi: 10.1029/ $2005 \mathrm{GC} 001202$

CHANDA, P. \& FANTLE, M.S. (2017): Quantifying the effect of diagenetic recrystallization on the $\mathrm{Mg}$ isotopic composition of marine carbonates.- Geochim. Cosmochim. Acta, 204, 219-239. doi: 10.1016/j.gca.2017.01.010

CISCATO, E.R., BONTOGNALI, T.R.R. \& VANCE, D. (2018): Nickel and its isotopes in organic-rich sediments: implications for oceanic budgets and a potential record of ancient seawater-- Earth Planet. Sc. Lett., 494, 239-250. doi: 10.1016/j. eps1.2018.04.061

COPLEN, T.B. (2011): Guidelines and recommended terms for expression of stable-isotope-ratio and gas-ratio measurement results.- Rapid Commun. Mass Spectrom., 25, 2538-2560. doi: 10.1002/rcm.5129

DE SOUZA, G.F., REYNOLDS, B.C., KICZKA, M. \& BOURDON, B. (2010): Evidence for mass dependent isotopic fractionation of strontium in a glaciated gra- nitic watershed.- Geochim. Cosmochim. Acta, 74/9, 2596-2614. doi: 10.1016/j. gca.2010.02.012

FANTLE, M.S. \& HIGGINS, J. (2014): The effects of diagenesis and dolomitization on $\mathrm{Ca}$ and $\mathrm{Mg}$ isotopes in marine platform carbonates: Implications for the geochemical cycles of Ca and Mg.- Geochim. Cosmochim. Acta, 142, 458-481. doi: 10.1016/j.gca.2014.07.025

FANTLE, M.S., \& TIPPER, E.T. (2014): Calcium isotopes in the global biogeochemical Ca cycle: Implications for development of a Ca isotope proxy.-Earth-Sci. Rev., 129, 148-177. doi: 10.1016/j.earscirev.2013.10.004

FIETZKE, J. \& EISENHAUER, A. (2006): Determination of temperature-dependent stable strontium isotope $\left({ }^{88} \mathrm{Sr} /{ }^{86} \mathrm{Sr}\right)$ fractionation via bracketing standard MC-ICPMS.- Geochem. Geophys. Geosy., 7/8, Q08009. doi: 10.1029/2006GC001243

GALL, L., WILLIAMS, H., SIEBERT, C., HALLIDAY, A., HERRINGTON, R. \& HEIN, J. (2013). Nickel isotopic compositions of ferromanganese crusts and the constancy of deep ocean inputs and continental weathering effects over the Cenozoic.- Earth Planet Sc. Lett., 375, 148-155. doi: 10.1016/j.epsl.2013.05.019

GALY, A., BAR-MATTHEWS, M., HALICZ, L., \& O'NIONS, R.K. (2002). Mg isotopic composition of carbonate: insight from speleothem formation.- Earth Planet Sc. Lett., 201/1, 105-115. doi: 10.1016/S0012-821X(02)00675-1

GILLEAUDEAU, G.J., FREI, R., KAUFMAN, A.J., KAH, L.C., AZMY, K., BARTLEY, J.K., CHERNYAVSKIY, P. \& KNOLL, A.H. (2016): Oxygenation of the mid-Proterozoic atmosphere: clues from chromium isotopes in carbonates.- Geochem. Perspec. Lett., 2, 178-187. doi: 10.7185/geochemlet.1618

GUEGUEN, B., ROUXEL, O., ROUGET, M.-L., BOLLINGER, C., PONZEVERA, E., GERMAIN, Y. \& FOUQUET, Y. (2016): Comparative geochemistry of four ferromanganese crusts from the Pacific Ocean and significance for the use of $\mathrm{Ni}$ isotopes as palaeoceanographic tracers.- Geochim. Cosmochim. Acta, 189, 214-235. doi: 10.1016/j.gca.2016.06.005

GUO, B., ZHU, X., DONG, A., YAN, B., SHI, G. \& ZHAO, Z. (2019): Mg isotopic systematic and geochemical applications: a critical review.- J. Asian Earth Sci., 176, 368-385. doi: 10.1016/j.jseaes.2019.03.001

HALICZ, L., SEGAL, I., FRUCHTER, N., STEIN, M. \& LAZAR, B. (2008): Strontium stable isotopes fractionate in the soil environments?- Earth Planet Sc. Lett., 272/1-2, 406-411. doi: 10.1016/j.epsl.2008.05.005

HIGGINS, J.A., BLÄTTLER, C.L., LUNDSTROM, E.A., SANTIAGO-RAMOS, D.P., AKHTAR, A.A., CRÜGER, AHM, A.-S., BIALIK, O., HOLMDEN, C., BRADBURY, H., MURRAY, S.T. \& SWART, P.K. (2018): Mineralogy, early marine diagenesis, and the chemistry of shallow-water carbonate sediments.- Geochim. Cosmochim. Acta, 220, 512-534. doi: 10.1016/j.gca.2017.09.046

HIPPLER, D., EISENHAUER, A. \& NÄGLE, T.F. (2006): Tropical Atlantic SST history inferred from $\mathrm{Ca}$ isotope thermometry over the last $140 \mathrm{ka}$.- Geochim. Cosmochim. Acta, 70, 90-100. doi: 10.1016/j.gca.2005.07.022.

HU, Z., HU, W., LIU, C., SUN, F., LIU, Y. \& LI, W. (2019): Conservative behavior of $\mathrm{Mg}$ isotopes in massive dolostones: From diagenesis to hydrothermal reworking.Sediment Geol., 381, 65-75. doi: 10.1016/j.sedgeo.2018.12.007

KIMMIG, S.R. \& HOLMDEN, C. (2017): Multi-proxy geochemical evidence for primary aragonite precipitation in a tropical-shelf 'calcite sea' during the Hirnantian glaciation.- Geochim. Cosmochim. Acta, 206, 254-272. doi: 10.1016/j. gca.2017.03.010

KRABBENHÖF, A., EISENHAUER, A., BÖHMA, F., VOLLSTAEDT, H., FIETZKE, J., LIEBETRAU, V., AUGUSTIN, N., PEUCKER-EHRENBRINK, B., MÜLLER, M.N., HORN, C., HANSEN, B.T., NOLTE, N. \& WALLMANN, K. (2010): Constraining the marine strontium budget with natural strontium isotope fractionations $\left({ }^{87} \mathrm{Sr} /{ }^{86} \mathrm{Sr} * \delta^{88} / 86 \mathrm{Sr}\right)$ of carbonates hydrothermal solutions and river waters.- Geochim. Cosmochim. Acta, 74, 4097-4109. doi: 10.1016/j. gca.2010.04.009

LI, W., BIALIK, O.M., WANG, X., YANG, T., HU, Z., HUANG, Q., ZHAO, S. \& WALDMANN, N.D. (2019): Effects of early diagenesis on Mg isotopes in dolomite: the roles of $\mathrm{Mn}(\mathrm{IV})$-reduction and recrystallization.-Geochim. Cosmochim. Acta, 250, 1-17. doi: 10.1016/j.gca.2019.01.029

LI, W.-Y., TENG, F.-Z., KE, S., RUDNICK, R.L., GAO, S., WU, F.-Y. \& CHAPPELL, B.W. (2010): Heterogeneous magnesium isotopic composition of the upper continental crust.-Geochim. Cosmochim. Acta., 74/23, 6867-6884. doi: 10.1016/j. gca.2010.08.030

LITTLE, S.H., ARCHER, C., MILNE, A., SCHLOSSER, C., ACHTERBERG, E.P., LOHAN, M.C. \& VANCE, D. (2018): Paired dissolved and particulate phase $\mathrm{Cu}$ isotope distributions in the South Atlantic.- Chem. Geol., 502, 29-43. doi: 10.1016/j.chemgeo.2018.07.022

LITTLE, S.H., VANCE, D., MCMANUS, J., SEVERMANN, S. \& LYONS, T.W. (2017): Copper isotope signatures in modern marine sediments.- Geochim. Cosmochim. Acta, 212, 253-273. doi: 10.1016/j.gca.2017.06.019

LITTLE, S.H., VANCE, D., WALKER-BROWN, C. \& LANDING, W. (2014): The oceanic mass balance of copper and zinc isotopes investigated by analysis of their inputs and outputs to ferromanganese oxide sediments.- Geochim. Cosmochim. Acta, 125, 673-693. doi: 10.1016/j.gca.2013.07.046 
MARÉCHAL, C.N., TÉLOUK, P. \& ALBARÈDE, F. (1999): Precise analysis of copper and zinc isotopic compositions by plasma-source mass spectrometry.-Chem. Geol., 156, 251-273. doi: 10.1016/S0009-2541(98)00191-0

MÍKOVÁ, J. (2012): Strontium isotopic composition as tracer of weathering processes, a review with respect to James Ross Island, Antarctica.- Czech Polar Rep., 2/1, 20-30. doi: 10.5817/CPR2012-1-3

MOYNIER, F., AGRANIER, A., HEZEL, D.C. \& BOUVIER, A. (2010): Sr stable isotope composition of Earth, the Moon, Mars, Vesta and meteorites.- Earth Planet. Sci. Lett., 300/3-4, 359-366. doi: 10.1016/j.eps1.2010.10.017

MOYNIER, F., VANCE, D., FUJII, T. \& SAVAGE, P. (2017): The Isotope Geochemistry of Zinc and Copper.- Rev. Mineral. Geochemistry, 82/1, 543-600. doi: 10.2138/rmg.2017.82.13

NÄGLER, T., EISENHAUER, A., MULLER, A., HEMLEBEN, C. \& KRAMERS, J. (2000): The $\delta^{44} \mathrm{Ca}$ temperature calibration on fossil and cultured Globigerinoides sacculifer: new tool for reconstruction of past sea surface temperatures.- Geochem. Geophys. Geosy., 1, 2000GC000091. doi: 10.1029/2000GC000091

OCKERT, C., GUSSONE, N., KAUFHOLD, S. \& TEICHERT, B.M.A. (2013): Isotope fractionation during $\mathrm{Ca}$ exchange on clay minerals in a marine environment.Geochim. Cosmochim. Acta, 112, 374-388. doi: 10.1016/j.gca.2012.09.041

OESER, R.A. \& VON BLANCKENBURG, F. (2020): Strontium isotopes trace biological activity in the Critical Zone along a climate and vegetation gradient.Chem. Geol., 119861. doi: 10.1016/j.chemgeo.2020.119861

OHNO, T. \& HIRATA, T. (2007): Simultaneous determination of mass-dependent isotopic fractionation and radiogenic isotope variation of strontium in geochemical samples by multiple collector-ICP-mass spectrometry.- Anal. Sci., 23/11, 1275-1280. doi: 10.2116/analsci.23.1275

PENNISTON-DORLAND, S., LIU, X.-M. \& RUDNICK, R.L. (2017): Lithium Isotope Geochemistry.- Rev. Mineral Geochem., 82/1, 165-217. doi: 10.2138/ rmg.2017.82.6

PISTINER, J.S. \& HENDERSON, G.M. (2003): Lithium-isotope fractionation during continental weathering processes.- Earth Planet Sc. Lett., 214, 327-339. doi: 10.1016/S0012-821X(03)00348-0

POGGE VON STRANDMANN, P.A.E., BURTON, K.W., JAMES, R.H., VAN CALSTEREN, P. \& GISLASON, S.R. (2010): Assessing the role of climate on uranium and lithium isotope behavior in rivers draining a basaltic terrain.- Chem. Geol., 270/1-4, 227-239. doi: 10.1016/j.chemgeo.2009.12.002

POGGE VON STRANDMANN, P.A.E., BURTON, K.W., JAMES, R.H., VAN CALSTEREN, P., GISLASON, S.R. \& MOKADEM, F. (2006): Riverine behaviour of uranium and lithium isotopes in an actively glaciated basaltic terrain.Earth Planet Sc. Lett., 251/1-2, 134-147. doi: 10.1016/j.eps1.2006.09.001

POGGE VON STRANDMANN, P.A.E., BURTON, K.W., JAMES, R.H., VAN CALSTEREN, P., GISLASON, S.R. \& SIGFÚSSON, B. (2008): The influence of weathering processes on riverine magnesium isotopes in a basaltic terrain.Earth Planet Sc. Lett., 276/1-2, 187-197. doi: 10.1016/j.epsl.2008.09.020

POGGE VON STRANDMANN, P.A.E., SCHMIDT, D.N., PLANAVSKY, N.J., WEI, G., TODD, C.L. \& BAUMANN, K.-H. (2019). Assessing bulk carbonates as archives for seawater Li isotope ratios.- Chem. Geol., 530, 119338. doi: 10.1016/j.chemgeo.2019.119338

RYAN, B.M., KIRBY, J.K., DEGRYSE, F., SCHEIDERICH, K. \& MCLAUGHLIN, M.J. (2014): Copper Isotope Fractionation during Equilibration with Natural and Synthetic Ligands.- Environ. Sci. Technol., 48/15, 8620-8626. doi: 10.1021/ es500764x

SAENGER, C. \& WANG, Z. (2014): Magnesium isotope fractionation in biogenic and abiogenic carbonates: implications for palaeoenvironmental proxies.- Quat. Sci. Rev., 90, 1-21. doi: 10.1016/j.quascirev.2014.01.014

SAUZÉAT, L., RUDNICK, R.L., CHAUVEL, C., GARCON, M. \& TANG, M. (2015): New perspectives on the Li isotopic composition of the upper continental crust and its weathering signature.- Earth Planet Sc. Lett., 428, 181-192.82. doi: 10.1016/j.eps1.2015.07.032

SCHEIDERICH, K., AMINI, M., HOLMDEN, C. \& FRANCOIS, R. (2015): Global variability of chromium isotopes in seawater demonstrated by Pacific Atlantic and Arctic Ocean samples.- Earth Planet Sc. Lett., 423, 87-97. doi: 10.1016/j.eps1.2015.04.030

SCHER, H.D., GRIFFITH, E.M. \& BUCKLEY, W.P.JR (2013): Accuracy and precision of ${ }^{88} \mathrm{Sr} /{ }^{86} \mathrm{Sr}$ and ${ }^{87} \mathrm{Sr} /{ }^{86} \mathrm{Sr}$ measurements by MC-ICPMS compromised by high barium concentrations.- Geochem. Geophys. Geosy., 15, 499-508. doi: 10.1002/2013GC005134

SCHOENBERG, S., ZINK, M., STAUBWASSER, M. \& VON BLANCKENBURG, F. (2008): The stable Cr isotope inventory of solid Earth reservoirs determine by double spike MC-ICP-MS.- Chem. Geol., 249/3-4, 294-306. doi: 10.1016/j. chemgeo.2008.01.009

SEMENISHCHEV, V.S. \& VORONINA, A.V. (2020): Isotopes of Strontium: Properties and Applications.- In: PATHAK, P. \& GUPTA, D.K. (eds.): Strontium Contamination in the Environment, Springer International Publishing.

SEMENIUK, D., MALDONADO, M.T. \& JACCARD, S.L. (2016): Chromium uptake and adsorption in marine phytoplankton - implications for the marine chromium cycle.- Geochim. Cosmochim. Acta, 184, 41-54. doi: 10.1016/j. gca.2016.04.021

SHALEV, N., GAVRIELI, I., HALICZ, L., SANDLER, A., STEIN, M. \& LAZAR, B. (2017): Enrichment of $88 \mathrm{Sr}$ in continental waters due to calcium carbonate precipitation.- Earth Planet. Sci. Lett., 459, 381-393. doi: 10.1016/j.eps1.2016.11.042

TAKANO, S., TANIMIZU, M., HIRATA, T. \& SOHRIN, Y. (2014): Isotopic constraints on biogeochemical cycling of copper in the ocean.- Nat. Commun., 5, 5663. doi: $10.1038 /$ ncomms6663

TENG, F.Z. (2017): Magnesium Isotope Geochemistry.- Rev. Mineral. Geochem., 82/1, 219-287. doi: 10.2138/rmg.2017.82.7

TENG, F.-Z., DAUPHAS, N. \& WATKINS, J.M. (2017): Non-Traditional Stable Isotopes: Retrospective and Prospective.- Rev. Mineral. Geochem., 82/1, 1-26. doi: 10.2138/rmg.2017.82.1

TENG, F.-Z., MCDONOUGH, W.F., RUDNICK, R.L., DALPÉ, C., TOMASCAK, P.B., CHAPPELL, B.W. \& GAO, S. (2004): Lithium isotopic composition and concentration of the upper continental crust.- Geochim. Cosmochim. Acta, 68/20, 4167-4178. doi: 10.1016/j.gca.2004.03.031

THOMPSON, C.M. \& ELLWOOD, M.J. (2014): Dissolved copper isotope biogeochemistry in the Tasman Sea, SW Pacific Ocean.- Mar. Chem., 165, 1-9. doi: 10.1016/j.marchem.2014.06.009

VANCE, D., ARCHER, C., BERMIN, J., PERKINS, J., STATHAM, P.J., LOHAN, M.C., ELLWOOD, M.J. \& MILLS, R.A. (2008). The copper isotope geochemistry of rivers and the oceans.- Earth Planet Sc. Lett., 274/1-2, 204-213. doi: 10.1016/j.eps1.2008.07.026

VOLLSTAEDT, H., EISENHAUER, A., WALLMANN, K., BÖHM, F., FIETZKE, J., LIEBETRAU, V., KRABBENHÖFT, A., FARKAŠ, J., TOMAŠOVÝCH, A., RADDATZ, J. \& VEIZER, J. (2014): The Phanerozoic $\delta 88 / 86 \mathrm{Sr}$ record of seawater: new constraints on past changes in oceanic carbonate fluxes.-Geochim. Cosmochim. Acta, 128, 249-265. doi: 10.1016/j.gca.2013.10.006

WAKAKI, S., OBATA, H., TAZOE, H. \& ISHIKAWA, T. (2017): Precise and accurate analysis of deep and surface seawater $\mathrm{Sr}$ stable isotopic composition by double-spike thermal ionization mass spectrometry.-Geochem. J., 51/3, 227-239. doi: 10.2343/geochemj.2.0461

WIMPENNY, J., COLLA, C.A., YIN, Q.-Z., RUSTAD, J.R. \& CASEY, W.H. (2014): Investigating the behaviour of $\mathrm{Mg}$ isotopes during the formation of clay minerals.Geochim. Cosmochim. Acta, 128, 178-194. doi: 10.1016/j.gca.2013.12.012 